\title{
Mitigation Plan and Water Harvesting of Flashflood in Arid Rural Communities Using Modelling Approach: A Case Study in Afouna Village, Egypt
}

\author{
Omar M. Abdeldayem 1,2, Omar Eldaghar ${ }^{1,3}{ }^{(0)}$, Mohamed K. Mostafa ${ }^{4}(\mathbb{D}$, \\ Mahmoud M. Habashy ${ }^{1,2}$, Ahmed A. Hassan ${ }^{1}$, Hossam Mahmoud ${ }^{5}$, Karim M. Morsy ${ }^{6} \mathbb{D}$, \\ Ahmed Abdelrady 2,7,*(D) and Robert W. Peters 8 \\ 1 Environmental Engineering Program, Zewail City of Science and Technology, Plot 12578, Ahmed Zewail \\ Road, October Gardens, 6th of October City, Giza 12573, Egypt; \\ s-omar.abdel-dayem@zewailcity.edu.eg (O.M.A.); s-omar.eldaghar@zewailcity.edu.eg (O.E.); \\ s-mahmoud.habashi@zewailcity.edu.eg (M.M.H.); s-ahmedalaa@zewailcity.edu.eg (A.A.H.) \\ 2 Department of Environmental Engineering and Water Technology, IHE Delft Institute for Water Education, \\ Westvest 7, 2611AX Delft, The Netherlands \\ 3 Department of Built Environment, School of Engineering, Aalto University, 02150 Espoo, Finland \\ 4 Faculty of Engineering and Technology, Badr University in Cairo (BUC), Cairo 11829, Egypt; \\ m_khaled@buc.edu.eg \\ 5 Department of Irrigation and Hydraulics, Cairo University, Giza 12613, Egypt; hossam.ham@gmail.com \\ 6 Department of Sanitary and Environmental Engineering, Cairo University, Giza 12613, Egypt; \\ kareemmorsy@ymail.com \\ 7 Department of Water Management, Delft University of Technology, 2600 GA Delft, The Netherlands \\ 8 Department of Civil, Construction, and Environmental Engineering, University of Alabama at Birmingham, \\ Birmingham, AL 35294, USA; rwpeters@uab.edu \\ * Correspondence: A.R.A.Mahmoud@tudelft.nl
}

Received: 27 July 2020; Accepted: 8 September 2020; Published: 14 September 2020

\begin{abstract}
This paper aims to propose methods to mitigate the risks of flash flood events in arid rural communities with poor infrastructure. A flash flood management case study was conducted at Afouna Village in Egypt, which is characterized by an arid climate and faced a devasting flash flood in 2015. First, the flash flood was modelled and it was found that it corresponds to a 100 year return period flood that led to an almost 13 million $\mathrm{m}^{3}$ total runoff volume. A structural protection approach, using an artificial infiltration pond, was applied to mitigate the flooding risks through water harvesting and recharging the groundwater of the Moghra aquifer. In this study, a novel approach was proposed, which is substituting the low permeability silty sand $\left(2.0 \times 10^{-4} \mathrm{~m} / \mathrm{s}\right)$ in the pond area with a high permeability one $\left(9.6 \times 10^{-3} \mathrm{~m} / \mathrm{s}\right)$, which will enhance water harvesting and reduce direct evaporation. Modern techniques of hydrological modelling were utilized in order to achieve the optimal use, and harvesting, of flash flood water.
\end{abstract}

Keywords: artificial infiltration pond; flash flood; flood risk management; hydrological modelling; water harvesting

\section{Introduction}

A flash flood is one of the most dangerous kinds of floods due to the fact of its fast occurrence, without previous warning [1,2]. The flash flood is a natural disaster with devastating capabilities that destroys houses, infrastructures, properties, cultivated crops, and threatens lives, especially in arid, mountainous regions [3,4]. Usually, flash floods are produced during a short time after a rainfall event, mostly with conditions like steep slopes, and absence of vegetation $[5,6]$. The risk and the intensity 
of flash floods are determined by different factors, like the intensity of the rainfall, its location and distribution, vegetation cover and its type, and the soil water content and its type [7].

In recent years, flash flood occurrences have become more frequent, resulting in loss of human life, damage of properties, and destruction of agricultural lands in Egypt [8-10]. In October 2019, a series of heavy rains that occurred due to Mediterranean hurricane, "medicane", on the coastline of Egypt, led to precipitation of $200 \mathrm{~mm}$, which is 10 times the average precipitation of the same period [11,12]. The unpredicted high intensities of precipitation and medicanes are linked to climate change that the earth is currently facing, especially in the Mediterranean region [13]. The recorded history of flash floods is not recent, however; it can be traced back to 1915 when a 43-mm rainfall event occurred in Cairo City, the capital of Egypt, resulting in coverage of trams with mud [14]. Flash floods have occurred in 1976, 1982, 1984, 1994, and 1995 in different areas in Upper Egypt, Sinai, and the Red Sea governorates [15-17]. In 2015, a series of flash floods occurred in different areas in Alexandria, Sinai, and Beheira governorates, leading to catastrophic losses in lives and properties [18]. Afouna village is a village in Beheira governorate that was adversely affected by heavy rainfall, which occurred between 3 and 5 November 2015, causing significant economic losses in lives, agricultural areas, as well as extensive damage to the roads [19]. At least 24 citizens lost their lives and 35 were injured as a result of the heavy rainfall [20]. The total damaged agricultural land was estimated to be approximately $68.8 \mathrm{~km}^{2}$. According to the Directorate of Veterinary Medicine, the affected region in Afouna Village resulted in an estimated loss of 1509 heads of livestock and 38,000 chickens [20].

There are two main types of flash flood risk reduction strategies, which are structural and non-structural [21-24]. The beginning of the twentieth century witnessed the use of engineering structures as a keystone measure for flood risk reduction, for better development purposes. Usually, the structural measures target adjusting, moderating, or redirecting the flow of flash flood streams [25-27]. The rainfall structural protection systems can be classified based on the runoff generating process, catchment size, and storage type $[28,29]$. The traditional methods of structural protection include dams and ditches. Between the 1960s and 1980s, structures such as dikes, embankments, dams, polders, diversion channels, and culverts have been widely constructed $[25,30]$. The conveying approach is widely utilized due to its cost-effective advantages, especially for newly developed areas; however, it is difficult to accommodate such a protection technique in a fully developed area [26,31]. To a large degree, it is believed that structural measures can directly reduce the magnitude of flash floods and control it over the short term. However, in the long term, some of these measures' abilities decrease, due to various factors, including unplanned development, change of land use, and population growth in the flood protected areas; hence, catastrophic flood losses may occur in any of these cases [32,33].

Water is an important aspect that influences the environment, society, and economy [34-36]. Additionally, it contributes to several sustainable development goals (SDG) goals that the United Nations is currently adopting [37]. Furthermore, Egypt is expected to face water scarcity challenges, due to overpopulation, climate change, and the Grand Ethiopian Renaissance Dam [38-40]. There is a strong need to encourage both harvesting of rainwater and for directing runoff water into systems of drains that can recharge groundwater [41-44]. Rainwater harvesting decreases peak flows and reduces flooding and damage resulting from flooding [45-48]. Flooding can be controlled by the creation of basins at lower grounds to collect runoff; the runoff water, when collected, can thereby be transported away as the rainfall intensifies [49-51]. This approach could turn otherwise devastating storm waters into a useful resource for agriculture [51,52]. To mitigate the effects of flooding, engineering-based solutions, such as the construction of new dykes, diversions, and flood retention zones, can be used [52-54]. Another approach, infiltration ponds, are deemed to be a sustainable water harvesting option, where the runoff water is captured in a ponding area and infiltrated into the groundwater table. It is more economical and does not have significant environmental impacts [55,56]. With proper rainwater utilization, water availability can be enhanced, the risk of flooding decreased, and farming, city greens, and ecosystems can be upgraded [57]. 
The primary objective of this study is to develop a sustainable flash flood risk mitigation and management strategy, for arid rural communities that are threatened by flash floods in addition to conserving wasted water resources. This problem affects the infrastructure of the village and has adverse effects on citizens. No researcher has discussed and suggested any approach to this issue at the investigated site. Furthermore, many rural Egyptian cities experience this problem. In this study, a structural protection approach, using an artificial infiltration pond, was applied. A novel approach was proposed, which is substituting the low permeability soil in the bottom of the pond with a high permeability one to enhance groundwater recharge and reduce direct evaporation. A sequence of hydrological-hydraulic-groundwater software for flash flood management has been applied. The mitigation and management strategies were conducted at one of the villages in Egypt (Afouna Village) which is classified as in an arid rural region, and which has been previously affected by a devasting flood. This study also provides a guideline for flash flood risk reduction in areas with similar geographical conditions (arid climate and frequently faces serious flash floods).

\section{Materials and Methods}

\subsection{Study Area}

Afouna Village is located in the western region of Beheira governorate in Egypt between the latitude of $30^{\circ} 30^{\prime} 52.53^{\prime \prime} \mathrm{N}$ to $30^{\circ} 22^{\prime} 32.51^{\prime \prime} \mathrm{N}$, and longitude of $30^{\circ} 12^{\prime} 11.09^{\prime \prime} \mathrm{E}$ to $30^{\circ} 1^{\prime} 18.04^{\prime \prime} \mathrm{E}$, as shown in Figure 1. The village's total area is estimated to be $148 \mathrm{~km}^{2}, 54 \%$ of which includes agricultural areas. The unoccupied desert is about $18.6 \mathrm{~km}^{2}$, which represents about $12.5 \%$ of the total area, while the inhabited area is about $49.4 \mathrm{~km}^{2}$, representing $33.5 \%$ of the total area. Based on provided data from the Egyptian government, the village has a population of 2500. Groundwater plays a vital role in land cultivation and reclamation projects in the region. Additionally, the livestock production sector has a significant contribution to the village economy. The village also has different industrial projects, such as salt extraction from the Gala Lake, fish aquaculture projects, and calcium oxide mining. According to the Köppen climate classification, which divides climates into five groups and each group is divided based on seasonal temperature and precipitation patterns, the village has an arid, hot desert climate (BWh), which means that it receives precipitation that ranges between 25 to $200 \mathrm{~mm}$ per year [58]. During the intense precipitation event, Afouna Village witnessed the devastation of more than 100 decrepit or informal settlements. The flash flood dramatically damaged the transport infrastructure, causing significant disruption to Afouna Village residents. The village is located in a depression with an elevation range from -34 to $50 \mathrm{~m}$. Since it is surrounded by a high plateau in the western part, with elevation ranging from 60 to $140 \mathrm{~m}$, the village is at a high risk of flooding, especially from the western part.

Satellite images were used to examine and visualize the changes in the land use overtime, at the same time frame as shown in Figure 2. In 1984, the land was mostly desert, and the flooding streamlines are easily distinguished from the satellite images. However, from 2002, land acquisition began housing and cultivation [59]. From 2002 to 2015, the cultivation of land increased significantly, even expanding over the flooding streams areas. Comparing the satellite image taken in 2015 with those taken in 2016 and 2017, several lands were swept away by the flood, especially those located within the flooding streamlines. 


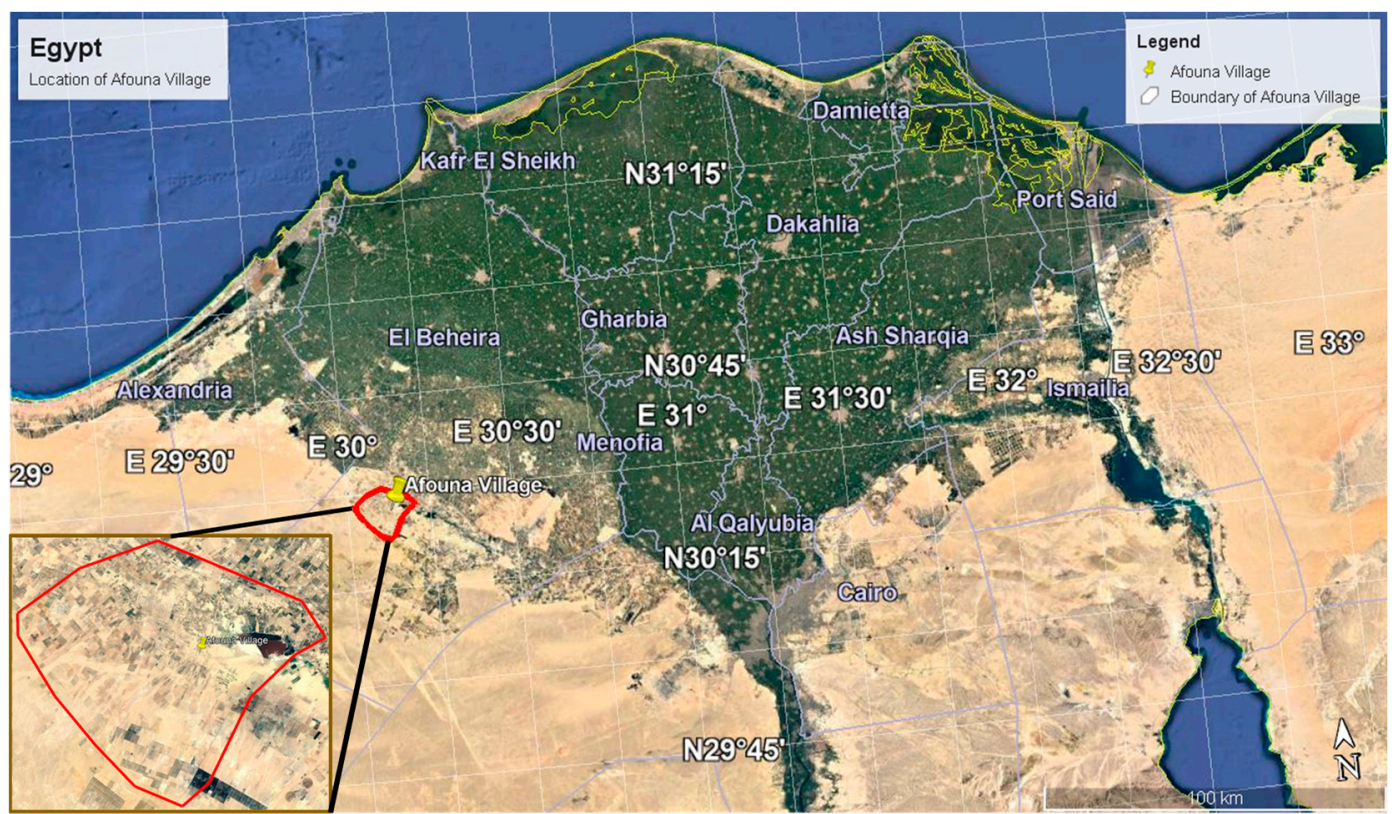

Figure 1. Location of Afouna Village.

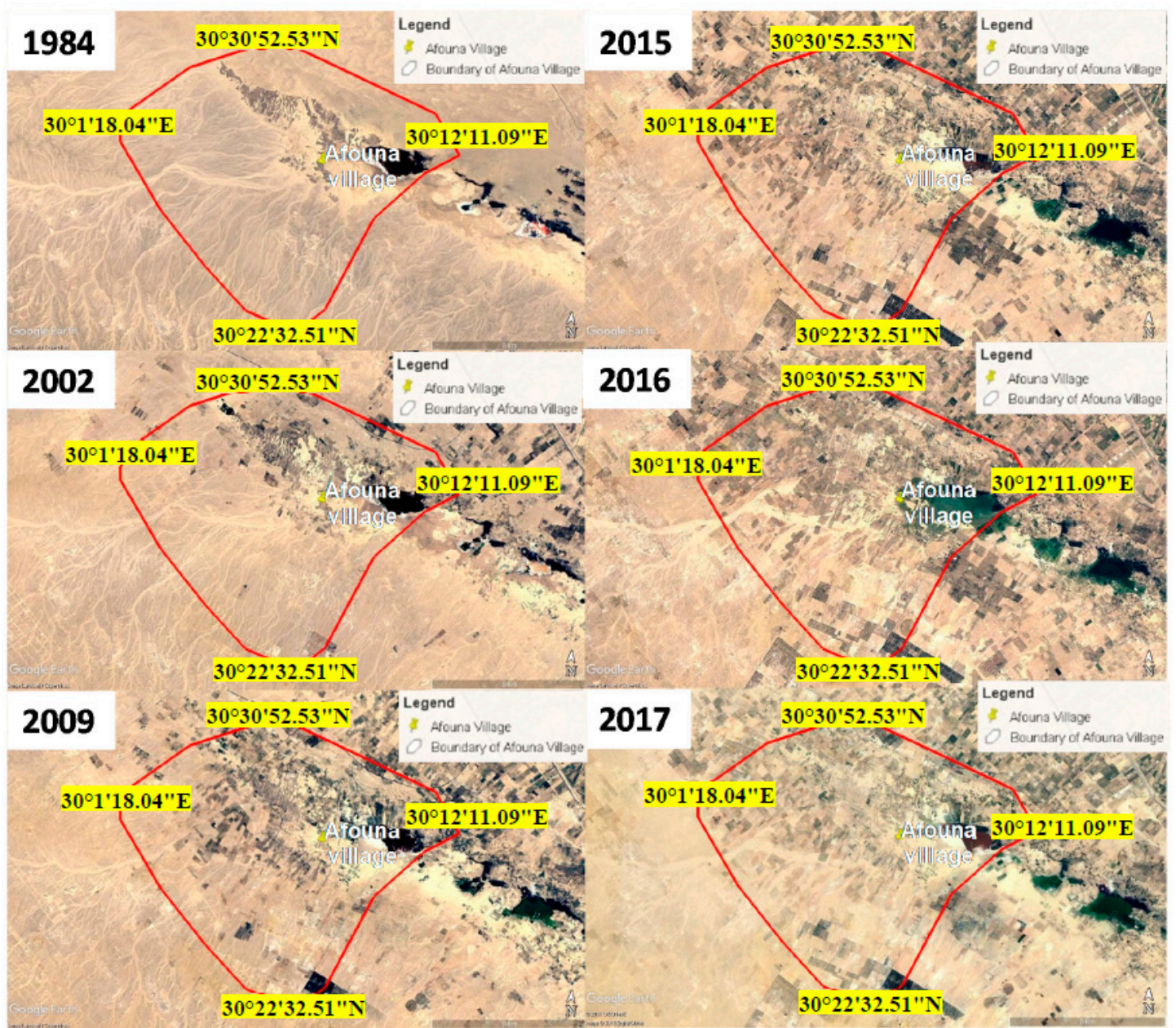

Figure 2. Land-use changes with time and the effect of the flooding. 


\subsection{Site Visit}

On 22 March 2018, a site visit was conducted to Afouna Village. The visit aimed to collect soil samples and to understand more about the characteristics of the area, the impact of the 2015 flash flood that occurred, and the mitigation strategy conducted after the flash flood. Generally, most of the buildings are single-story and made from white calcium carbonate bricks (Figure 3a). The flood streams led to the destruction of his agriculture land (Figure 3b). Going downstream to the village, disastrous effects on the village were noticed. Many empty houses were observed that had been destroyed by the flood, and were deserted by their owners, as shown in Figure 3c,d.
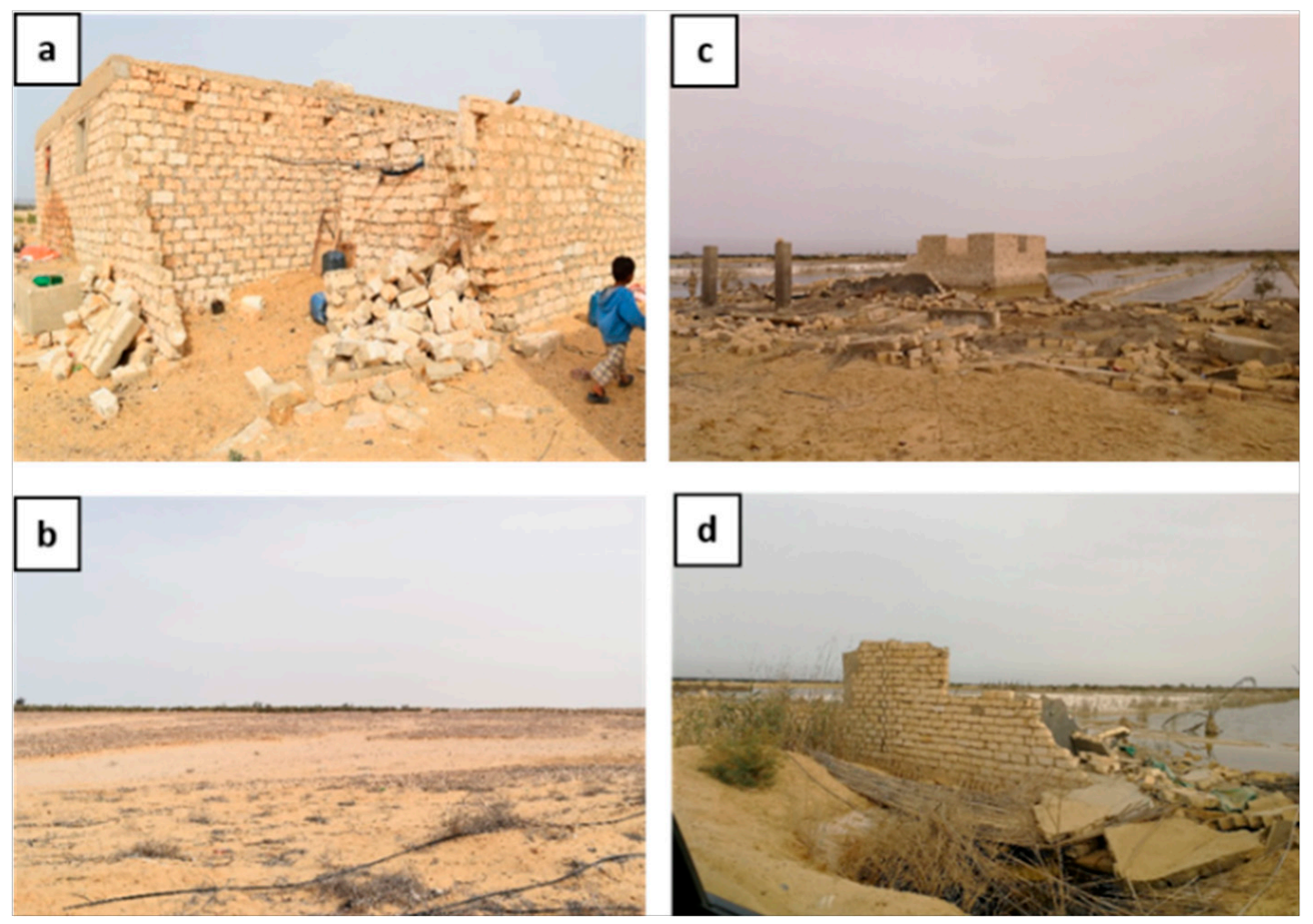

Figure 3. Consequences of a flash flood at Afouna Village: (a) damage to property, (b) one of the main flood stream paths in the village, (c) destruction of agricultural land, (d) wall collapsed in the main road.

\subsection{Hydrological Analysis}

Figure 4 provides the methodology flow chart and the integrated software that were utilized in this study to achieve an effective flood risk mitigation plan for Afouna Village. The software comprised Hyfran, Virtual Tour (VT) Builder, Watershed Modelling System (WMS 9.1), Hydrologic Modelling System (HEC-HMS), EPA's Storm Water Management Model (SWMM), and Hydrus 3D finite element analysis. These software are briefly described in Figure 4. 


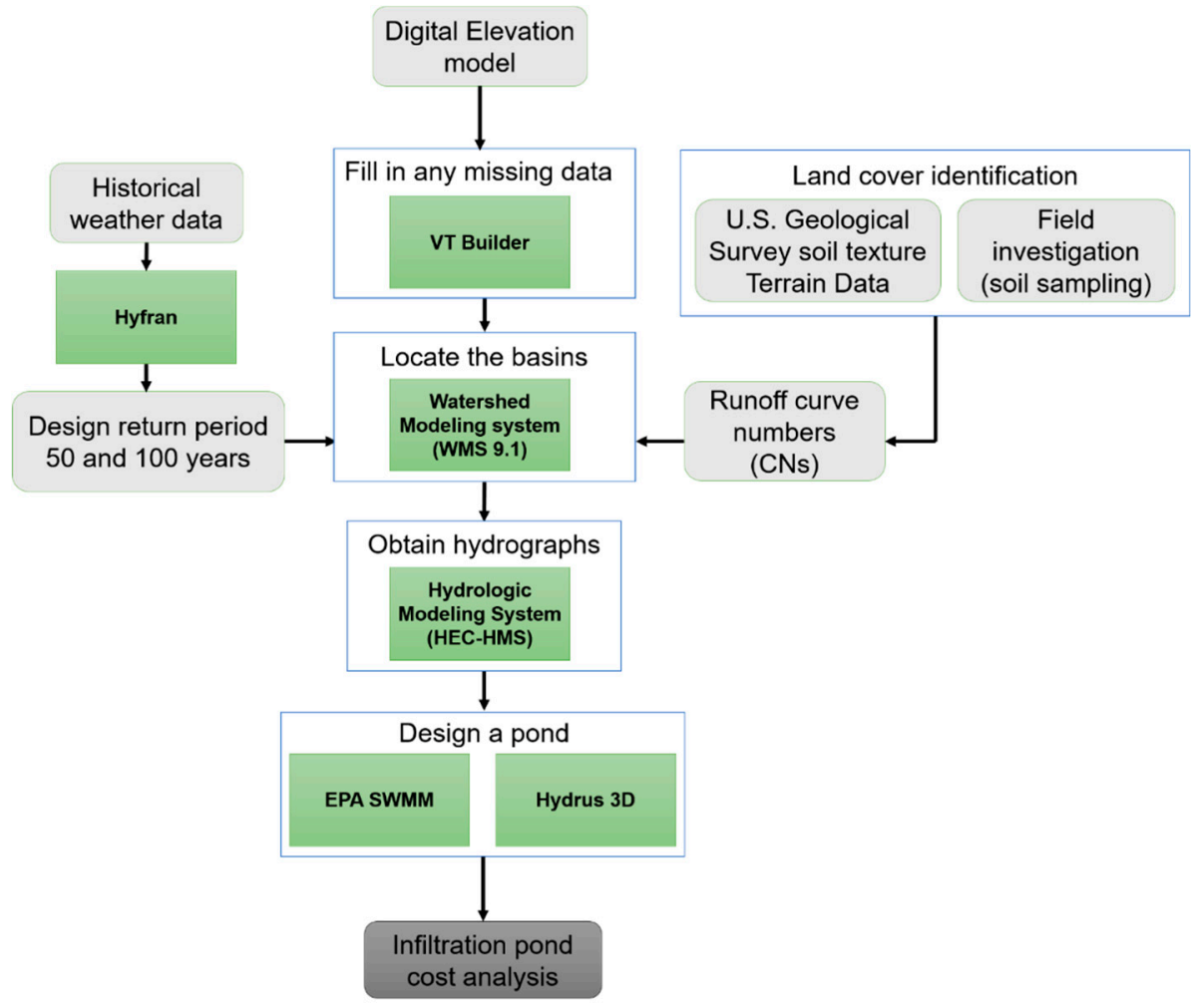

Figure 4. Flowchart of the integrated software used in this study.

\subsubsection{Digital Elevation Model}

Digital elevation models (DEMs) are arrays of repeatedly spaced values for elevation, referenced horizontally to a geographic coordinate system or the universal transverse mercator (UTM) projection. The shuttle radar topography mission (SRTM) $30 \times 30$ m digital elevation model was retrieved and then used to represent the terrain surface. VT Builder is a tool for processing and viewing geospatial data that was used to interpolate the missing data in the DEM files [60].

\subsubsection{Basin Model: WMS}

The basins were generated using the Watershed Modelling System (WMS 9.1), which was developed by Aquaveo Corporation. The retrieved processed DEMs were used by the WMS to delineate the watershed into basins and sub-basins. The basins and sub-basin flow direction and accumulated flow were computed. The flow directions were then used to create a flow path arc (polyline) for each sub-basin to represent the longest flow path. In order to run the WMS model, the curve number, and the design return period, must be estimated. The curve number depends on the soil texture data, which were determined using $2 \mathrm{~km}$ high-resolution United States Geological Survey (USGS) soil texture terrain data, as shown in Supplementary Figure S1. The USGS soil texture terrain data showed the soil in the Afouna area is generally sandy clay loam. According to the United States Department of Agriculture- Natural Resources Conservation Service (USDA-NRCS) 1984 method, it was determined that the curve number for the associated area has a hydrologic soil group C classification [61]. Generally, the sub-basin areas are exposed to extended dry periods before precipitation events, making the soil dry, and the moisture content is negligible. On that basis, the curve number was assumed to be 79 [61].

The Soil Conservation Service (SCS) curve number method was then used by the WMS to calculate the storage in the basins and the sub-basins using Equation (1) [62]. The lag time was calculated by the 
WMS using the Soil Conservation Service (SCS) method (Equation (2)). The SCS-CN method was then used to estimate the runoff of the studied watershed [63].

$$
S=\frac{1000}{C N-10}
$$

where $S$ is the maximum retention in the watershed (inches), and $C N$ is the SCS curve number for the watershed, as defined by the loss method.

$$
T_{\text {lag }}=L^{0.8} \frac{(S+1)^{0.7}}{1900 \sqrt{Y}}
$$

where $T_{\text {lag }}$ is the lag time (hours), $L$ is the hydraulic length of the watershed (feet), and $Y$ is the watershed slope $(\%)$.

\subsubsection{Rainfall Data Type Determination}

The global precipitation measurement (GPM) was used to determine the rainfall distribution of the 2015 peak storm, as it had a high temporal resolution of $30 \mathrm{~m}$ and $0.1^{\circ}$ spatial resolution. Additionally, this method allowed for obtaining a more location specialized rainfall distribution than the conventional Type I, Type II, and Type III rainfall distribution methods. The rainfall cumulative rainfall event was calculated, and the rainfall fraction shown in Figure 5 was then calculated [64].

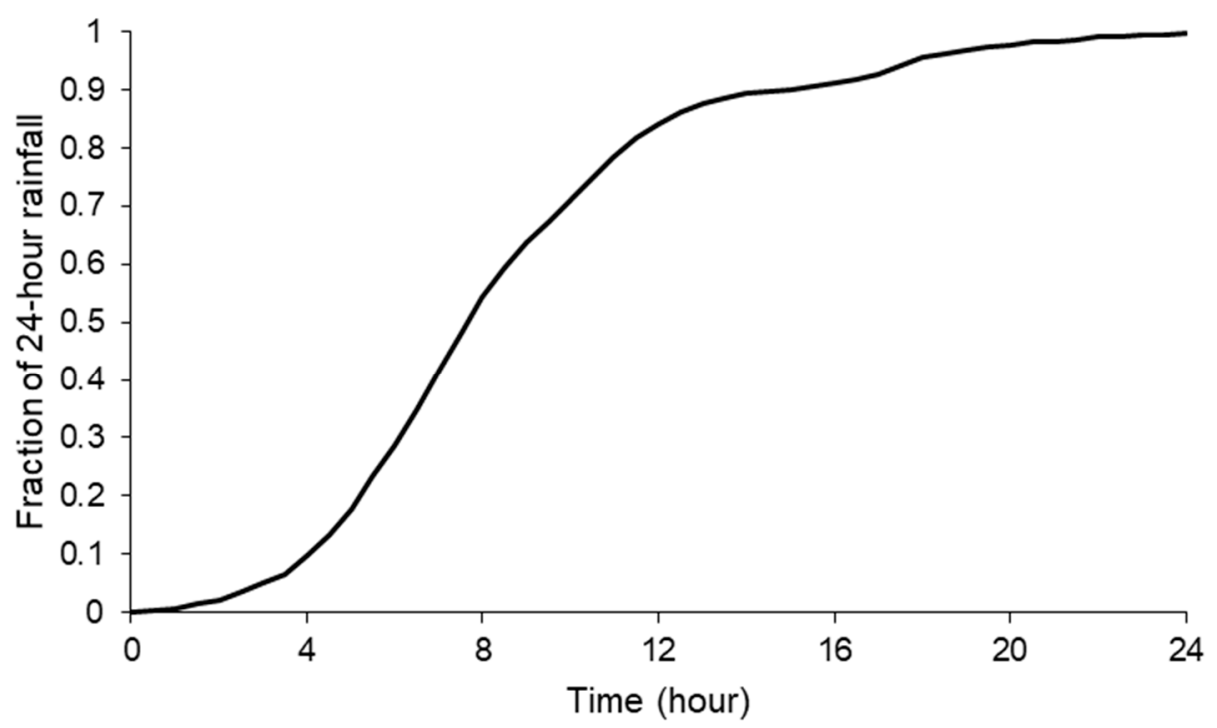

Figure 5. Fraction of 24-hour rainfall vs time.

\subsubsection{Accumulated Rainfall Data}

Since there is no rainfall monitoring system available close to the study area, the rainfall data were retrieved from Tropical Rainfall Measuring Mission (TRMM) satellite data. The TRMM uses a satellite related to National Aeronautics and Space Administration (NASA) and Japan's National Space Development Agency, which was first launched in 1997. It aims to observe tropical rainfall data and to provide a useful method for understanding the release of energy into the atmosphere, and hence a better prediction of the global climate. These data offer a practical tool for hydrological studies in ungauged areas. The daily accumulated TRMM precipitation data, which are generated from the research quality 3-hourly TRMM multi-satellite precipitation analysis TMPA (3B42) was used in calculating the return period. The precipitation data had a 0.25 -degree $\times 0.25$-degree resolution. The accumulated rainfall data was released daily from 31 December 1997 until 1 February 2018 [65]. 


\subsubsection{Return Period Calculations using Hyfran}

The calculating and choosing of the rainfall return period is an essential aspect for predicting the flooding discharge and quantity of the runoff. This is essential in designing the hydraulic structures and the level of protection for flood management [66]. Generally, there is a lack of precipitation data in arid and semi-arid regions for long periods of time. Therefore, it is difficult to predict the return period using the conventional method, using the recurrence interval shown in Equation (3).

$$
T=\frac{n+1}{m}
$$

where $T$ is the return period, $m$ is the rank of data corresponding to the event, with return period $T$, and $n$ is the number of years of data.

To overcome this problem, the Hyfran program was used to estimate the return period, using different statistical distributions. The Hyfran program offers 18 different statistical distributions which are available to fit data sets, which are independent, homogenous, and stationary. The Akaike information criterion (AIC) is a widely used method for the identification of optimum distribution out of a group of competing ones. To define the best analysis method, the AIC test was used to select the best distribution method [67]. The return period was calculated for two different groups of sub-watersheds in the studied ungauged region, as mentioned in Sections 2.3.3 and 2.3.4, and as shown in Supplementary Table S1. The TRMM satellite data were used in obtaining the annual maximum precipitation in the studied area, while the GPM was used for obtaining the rainfall distribution in the same area.

\subsubsection{Runoff Water: HEC-HMS}

HEC-HMS version 4.2.1, developed by the U.S. Army Corps Engineers, was used in this study to estimate different hydrological parameters, during the simulated flash floods, such as time to peak discharge, peak discharge flow, and runoff volume, for every sub-basin and basin in the study area. The HEC-HMS has different models, including basin models and meteorological models, which facilitate the runoff modelling process. A time parameter of $30 \mathrm{~min}$ was used, with the same parameters incorporated from the WMS that were mentioned in Section 2.3.2. The SCS curve number method was used for the calculation of water losses. It was also used as a transformation method for the calculation of lag time and time to peak. The lag routing method was employed for stream reaches.

\subsubsection{Soil Analysis}

Seven soil samples were collected at a depth of $7 \mathrm{~m}$ each, following the Egyptian code of soil sampling, using the rotary drilling method [68], at the proposed location of the pond. The collected samples were tested for (chloride $\left(\mathrm{Cl}^{-}\right)$, sulfur trioxide $\left(\mathrm{SO}_{3}\right)$, organic matter, $\mathrm{pH}$, permeability, and sieve analyses) according to the Egyptian code for soil analysis, in the soil laboratory at the Housing and Building National Research Center (HBRC) in Cairo, Egypt. The samples were tested according to EN 1744-1:2009 standards for $\mathrm{Cl}^{-}, \mathrm{SO}_{3}$, organic matter, and $\mathrm{pH}$. The coefficient of permeability was analyzed for the collected samples using a constant head permeameter.

\subsubsection{Rate of Sedimentation}

The sediment input in a retention pond in each period represents a minimum sediment yield for the drainage basin, and can be calculated using Equation (4) (given that the trap efficiency is $35 \%$ ).

$$
\mathrm{SV}=\frac{(\mathrm{SY} \times \mathrm{TE} \times \mathrm{A})}{\mathrm{dBD}}
$$


where SY, SV, dBD, TE, and A represent sediment yield (ton $/ \mathrm{km}^{2} /$ year), sediment volume in a retention pond for a given time interval $\left(\mathrm{m}^{3} /\right.$ year), dry bulk density of the sediment $\left(\mathrm{ton} / \mathrm{m}^{3}\right)$, trap efficiency of the retention pond $(\%)$, and drainage area $\left(\mathrm{km}^{2}\right)$, respectively. Values of these variables are listed below.

- $\quad$ TE using the Churchill curve is $35 \%$ [69].

- $\mathrm{dBD}$ is assumed to be $1.23 \mathrm{ton} / \mathrm{m}^{3}$ (average value).

- A is the drainage area, which is $405 \mathrm{~km}^{2}$.

- SY for the Nile delta region is assumed to be $40 \mathrm{ton} / \mathrm{km}^{2} /$ year

Therefore, the sediment volume is estimated to be about $461,000 \mathrm{~m}^{3} / \mathrm{year}$.

\subsubsection{Pond Design}

EPA's storm water management model (SWMM) was used for flash flood simulation for 50- and 100-year storm return period runoff and drainage, using $30 \mathrm{~min}$ time steps [70]. This software can be used in the planning, design, and analysis phases of related projects. The SWMM model allows users to articulate specific objectives, such as reducing runoff by using infiltration and storage means. The total inflow of the pond was retrieved from the HEC-HMS model for the required design. The coefficient of permeability was obtained from the soil analysis performed. The coefficient was then used to simulate infiltration in the pond. The proposed location of the pond was at latitude $30^{\circ} 26^{\prime} 30.77^{\prime \prime} \mathrm{N}$ and longitude $30^{\circ} 2^{\prime} 26.37^{\prime \prime} \mathrm{E}$, based on the delineation data obtained from WMS and the location of the soil samples taken. This specific location was selected as it is the collection point of delineated flooding streams that pose a risk to the village. The sizing of the pond was conducted for return periods of 50- and 100-years. The same methodology for the selection of suitable rainwater harvesting sites was conducted by Ramakrishnan et al. [71]. They used slope, permeability, porosity, runoff potential, stream order, and catchment area as primary criteria for selection of suitable sites for various rainwater harvesting systems in the KALI Watershed, Dahod district of Gujarat, India. Similarly, Durga Rao et al. [72] utilized land use, soil texture, slope, runoff potential, geology, proximity, and drainage as primary factors to identify suitable rainwater harvesting sites. During the design of the pond, it was assumed that the pond is initially empty and the boundary condition is free outfall, in case the water depth exceeded the height of the proposed pond. It is also worth noting that the evaporation and the infiltration were taken into consideration during the design of the pond.

\subsubsection{Hydrus 3D: Groundwater Recharge}

Hydrus 3D finite element analysis software was used to estimate the amount of water that can infiltrate, to recharge the groundwater of the Moghra aquifer, through the artificial pond. Hydrus 3D is a tool to build a model and simulate the groundwater recharge. A mesh was established for the pond area as per the pond dimensions and volume. The climatic data, topography, soil properties, and groundwater features of the studied area were inserted to the model in order to set its specific features [55]. Two different scenarios were studied: (a) Scenario 1, where the return period is 50 years and (b) Scenario 2, where the return period is 100 years [73]. The governing equations that were utilized by the Hydrus software to estimate the water flow in the unsaturated zone of the soil were Darcy's and Richard's equations, as illustrated in Equations (5) and (6). The equations were adopted to model the water flow in the unsaturated zone of soil, considering that soil is unsaturated, and that water is flowing in all the soil pores under pressure head $(h)$.

$$
\begin{gathered}
q=K(h) \times \nabla \mathrm{H} \\
\frac{\partial \theta}{\partial \mathrm{t}}=\frac{\partial}{\partial \mathrm{z}}\left(K(h) \frac{\partial \mathrm{h}}{\partial \theta} \frac{\partial \theta}{\partial \mathrm{z}}\right)+\frac{\partial K}{\partial \theta} \frac{\partial \theta}{\partial \mathrm{z}}
\end{gathered}
$$

where $q(\mathrm{~m} / \mathrm{s})$ is Darcy specific discharge flux, $K(h)(\mathrm{m} / \mathrm{s})$ is the hydraulic conductivity of soil, $\mathrm{H}(\mathrm{m})$ is the total potential head, $\mathrm{z}(\mathrm{m})$ is the elevation, and $\theta(-)$ is moisture content. The catchment characteristics 
such as topography, soil thickness, and presence of aquifer layers, porosity, hydraulic conductivity, storage coefficient, and capillary rise of the unsaturated zone were identified. Setting the modelling initial and boundary conditions was necessary to recognize the inflow and outflow conditions.

The boundary conditions that defined boundaries of the pond, which are utilized in the Hydrus model, are presented in Table 1.

Table 1. The boundary conditions set for the pond in the Hydrus model.

\begin{tabular}{lll}
\hline Item & Boundary & Condition \\
\hline 1. & Top layer boundary & $\begin{array}{l}\text { The top layer, defined as atmospheric boundary layer which obeys } \\
\text { the general conditions of contact with atmosphere }\end{array}$ \\
2. & Sides boundary & $\begin{array}{l}\text { The side boundaries defined as variable-flux boundaries to allow } \\
\text { water to flow in all directions according to its depth. } \\
\text { The bottom layer defined to represent the groundwater table, noting } \\
\text { that the groundwater table level is } 57 \mathrm{~m} \text { below the ground surface. }\end{array}$ \\
3. & Bottom layer boundary
\end{tabular}

\section{Results and Discussion}

\subsection{Basin Model: WMS}

The WMS produced a delineated large watershed of $405 \mathrm{~km}^{2}$. Additional control points $(1 \mathrm{~B}, 2 \mathrm{~B}$, $3 \mathrm{~B}, 4 \mathrm{~B}, 5 \mathrm{~B}, 6 \mathrm{~B}, 7 \mathrm{~B}$, and $8 \mathrm{~B}$ ) were identified to develop a more accurate hydrograph, as well as to have a better understanding of the flash flood flow at each sub-watershed, resulting into eight sub-watersheds. The morphological data are summarized in Table 2. It shows that the lag time is approximately 8 $h$, which reflects the time between the rainfall occurrence and runoff. This is an essential factor that is considered for flood alert systems and disaster management. The largest basin slope is 0.0169 , the largest stream slope is 0.0085 , and the maximum stream length is approximately $18.9 \mathrm{~km}$. 
Table 2. The morphology characteristics of the basins in the study area.

\begin{tabular}{|c|c|c|c|c|c|c|c|c|c|c|c|}
\hline No & $\begin{array}{l}\text { Basin } \\
\text { Name }\end{array}$ & Area $\left(\mathrm{km}^{2}\right)$ & $\begin{array}{l}\text { Basin } \\
\text { Slope } \\
(\mathrm{m} / \mathrm{m})\end{array}$ & $\begin{array}{c}\text { Max Flow } \\
\text { Slope } \\
(\mathrm{m} / \mathrm{m})\end{array}$ & $\begin{array}{c}\text { Max } \\
\text { Stream } \\
\text { Length }(\mathrm{m})\end{array}$ & $\begin{array}{c}\text { Max } \\
\text { Stream } \\
\text { Slope } \\
(\mathrm{m} / \mathrm{m})\end{array}$ & $\begin{array}{c}\text { Basin } \\
\text { Length (m) }\end{array}$ & $\begin{array}{c}\text { Basin } \\
\text { Perimeter } \\
\text { (m) }\end{array}$ & $\begin{array}{c}\text { Basin } \\
\text { Shape } \\
\text { Factor } \\
\left(\mathrm{mi}^{2} / \mathrm{mi}^{2}\right)\end{array}$ & $\begin{array}{c}\text { Basin } \\
\text { Average } \\
\text { Elevation } \\
\text { (m) }\end{array}$ & $\begin{array}{l}\text { Lag Time } \\
\text { (h) }\end{array}$ \\
\hline 1 & 1B & 83.5 & 0.0128 & 0.0042 & 16,091 & 0.0037 & 12,200 & 59,500 & 1.80 & 140 & 7.77 \\
\hline 2 & $2 B$ & 3.5 & 0.0122 & 0.0078 & 5241 & 0.0064 & 5900 & 17,600 & 9.73 & 30 & 3.61 \\
\hline 3 & $3 B$ & 44.9 & 0.0169 & 0.0083 & 14,146 & 0.0085 & 11,800 & 47,600 & 3.1 & 104 & 6.10 \\
\hline 4 & $4 \mathrm{~B}$ & 47.5 & 0.0137 & 0.0070 & 12,656 & 0.0067 & 10,800 & 46,300 & 2.47 & 124 & 6.63 \\
\hline 5 & $5 B$ & 39.1 & 0.0115 & 0.0047 & 16,371 & 0.0045 & 11,500 & 47,900 & 3.38 & 125 & 8.30 \\
\hline 6 & $6 \mathrm{~B}$ & 22.3 & 0.0100 & 0.0048 & 11,941 & 0.0037 & 9800 & 39,100 & 4.30 & 124 & 7.19 \\
\hline 7 & $7 \mathrm{~B}$ & 54.5 & 0.0104 & 0.0034 & 18,993 & 0.0033 & 13,400 & 67,900 & 3.30 & 133 & 9.67 \\
\hline 8 & $8 \mathrm{~B}$ & 109.7 & 0.0105 & 0.0037 & 18,076 & 0.0036 & 13,200 & 66,300 & 1.58 & 137 & 9.30 \\
\hline
\end{tabular}




\subsection{Accumulated Rainfall Data}

The precipitation data were extracted from the TRMM precipitation data. It was determined that the whole watershed could be divided into two main regions, 1 and 2, which have different rainfall intensities (see Figure 6a). Table 3 shows the historical yearly precipitation data in each region from 1998 to 2019 [74].

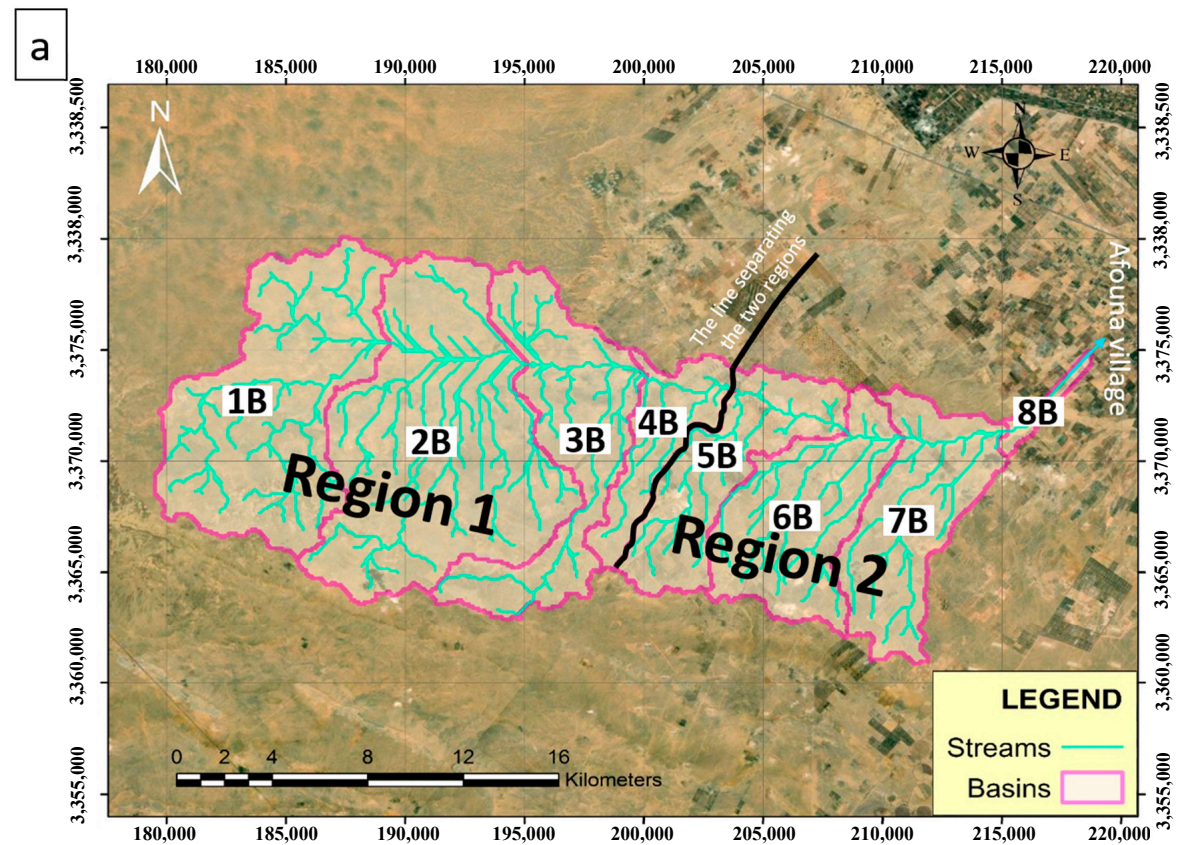

b
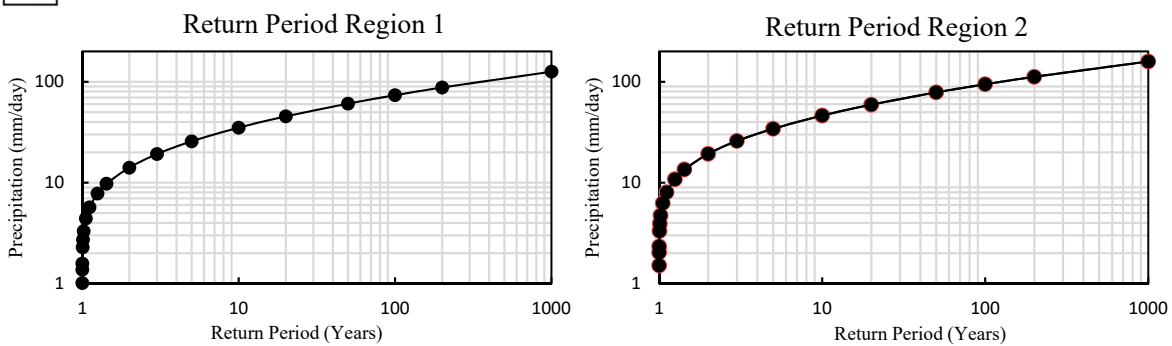

Figure 6. (a) Separating the watershed into two regions and (b) return period lognormal for Region 1 and Region 2.

Table 3. Annual maximum precipitation from 1998 to 2017 based on Tropical Rainfall Measuring Mission (TRMM) Satellite data.

\begin{tabular}{ccc}
\hline Regions & Region $\mathbf{1}(\mathbf{1 B}, \mathbf{2 B}, \mathbf{3 B}, \mathbf{4 B})$ & Region $\mathbf{2}(\mathbf{5 B}, \mathbf{6 B}, \mathbf{7 B}, \mathbf{8 B})$ \\
\hline Year & Annual Maximum & Precipitation $\mathbf{( m m})$ \\
\hline 1998 & 14.03 & 28.96 \\
1999 & 8.52 & 8.96 \\
2000 & 22.63 & 24.41 \\
2001 & 7.77 & 18.24 \\
2002 & 21.60 & 25.30 \\
2003 & 16.74 & 17.23 \\
2004 & 7.64 & 11.52 \\
2005 & 9.230 & 15.75 \\
2006 & 10.14 & 12.46 \\
\hline
\end{tabular}


Table 3. Cont.

\begin{tabular}{ccc}
\hline Regions & Region $\mathbf{1}(\mathbf{1 B}, \mathbf{2 B}, \mathbf{3 B}, \mathbf{4 B})$ & Region $\mathbf{2}(\mathbf{5 B}, \mathbf{6 B}, \mathbf{7 B}, \mathbf{8 B})$ \\
\hline Year & Annual Maximum & Precipitation $\mathbf{( m m})$ \\
\hline 2007 & 16.77 & 16.77 \\
2008 & 30.86 & 37.82 \\
2009 & 4.670 & 25.79 \\
2010 & 5.10 & 3.950 \\
2011 & 31.45 & 33.46 \\
2012 & 19.08 & 24.21 \\
2013 & 14.93 & 28.71 \\
2014 & 8.70 & 6.97 \\
2015 & 84.54 & 99.00 \\
2016 & 8.29 & 15.12 \\
2017 & 28.15 & 27.71 \\
2018 & 28.47 & 18.36 \\
2019 & 55.71 & 31.32 \\
\hline
\end{tabular}

\subsection{Return Period Using Hyfran}

The return period was calculated for Region 1 and Region 2, for the watersheds studied, using the TRMM precipitation data. Figure $6 \mathrm{~b}$ illustrates the return period versus the rainfall, according to the Akaike information criterion (AIC) test, which indicates the quality of statistical models for a set of data. The lowest AIC indicates the best fitting distribution, which was found to be the lognormal distribution for the return period calculation for the studied regions. A lower AIC indicates a better fitting. After calculating the return period, the November 2015 flash flood was found to be corresponding to a 100-year return period flash flood, as their precipitation was almost the same.

Upon searching the literature, it was found that lognormal distribution provided the best fit for arid and semi-arid regions. Abdulrazzak et al. [75] demonstrated that lognormal distribution provided the best fit for estimating the return period, for a case study in Medina city in Saudi Arabia. In addition, Patle [76] showed that the lognormal distribution provided the closest fit to the observed data for different return periods in the semi-arid Maharastra region. Moreover, Barkotulla et al. [77] reached the same conclusion that the lognormal distribution exhibited the best fit for Rajshahi semi-arid region. Tilahun [78] concluded that normal distribution fitting was not able to fit observations properly, and that the Gumbel and lognormal distributions were the best fitting models for return periods, for arid and semi-arid regions in Ethiopia. Moreover, Kwaku and Duke [79] illustrated that lognormal distribution was the most suited model to describe the annual one day maximum, and two to five days consecutive, compared to different fitting models in Accra, Ghana arid regions.

\subsection{Runoff Water: HEC-HMS}

The hydrographs at different control points of the watershed were retrieved from HEC-HMS (see Figure 7). There are several peaks at each control point for every return period. These hydropaths helped in determining the maximum amount of water that is expected to reach the village. Overall, the hydrographs can be assumed to be the same for the two return periods, as the same rainfall type was used for both scenarios. However, the time to peak is slightly different for the two return periods, especially for control points $1 \mathrm{C}, 2 \mathrm{C}, 3 \mathrm{C}, 4 \mathrm{C}, 5 \mathrm{C}$, and $6 \mathrm{C}$, as the precipitation intensity affects the time to peak. At control points $7 \mathrm{C}$ and $8 \mathrm{C}$, the time to peak is significantly different, as the first peak in the return period 50 years has a slightly higher flow than the second peak. Therefore, the time to peak was calculated for the first peak flow, not the second one, in order to simulate the most critical scenario. The total runoff volume that would affect Afouna Village can be assumed to be the flow at control point $8 \mathrm{C}$, which is about 9.3 million $\mathrm{m}^{3}$ for a 50 -year return period, and 13.3 million $\mathrm{m}^{3}$ for a 100 -year return period. This vast amount of water could be harvested and recharged to the groundwater in this area. 

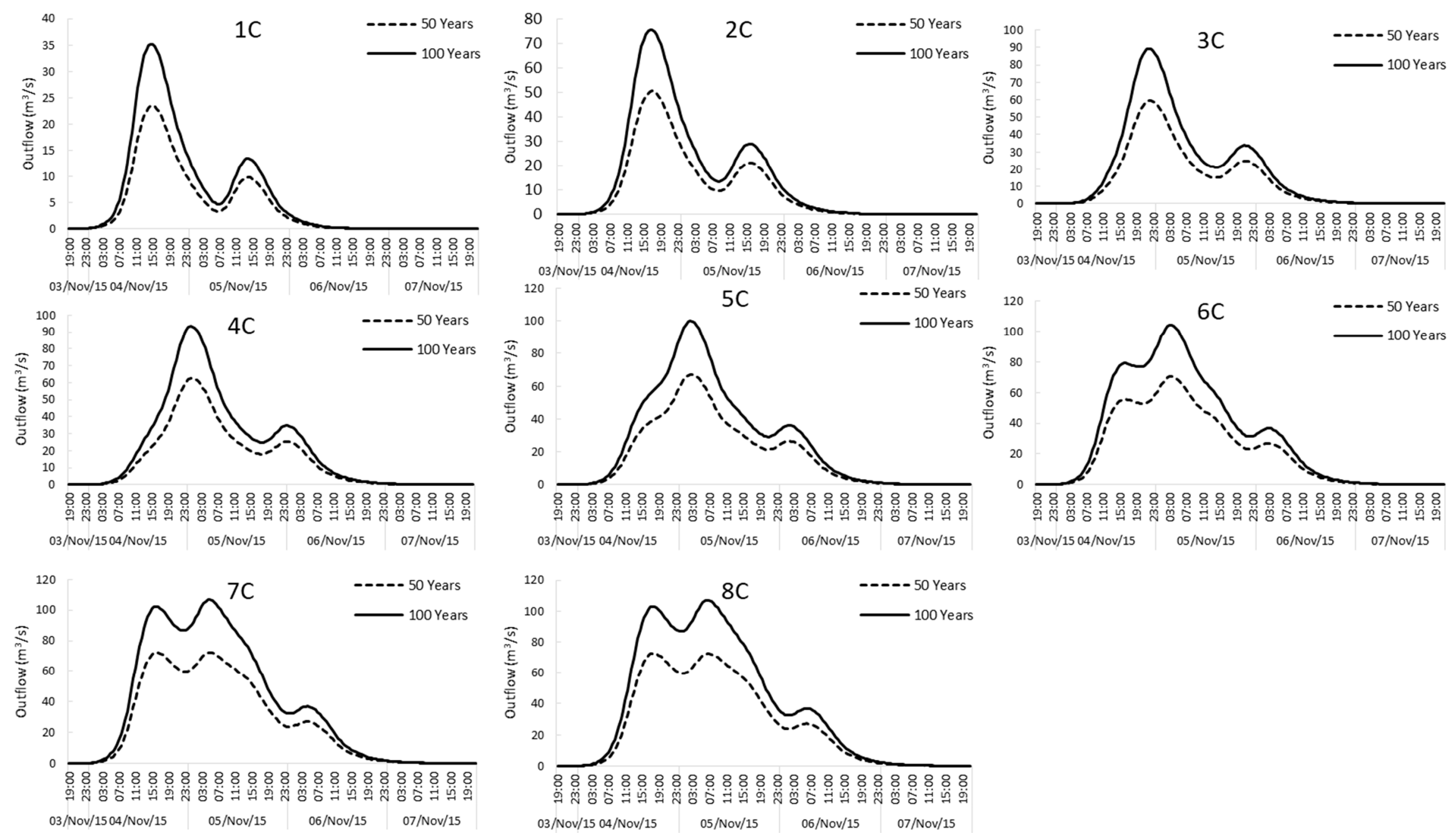

Figure 7. Streamflow vs Time/Date for 50-year and 100-year return periods. 


\subsection{Model Validation}

Since there are no flow measuring devices identified in the study area, the model validation was conducted using the testimonies of Afouna's citizens, regarding the flash flood. According to the testimonies of two families living at an elevation $18 \mathrm{~m}$ below sea level, the accumulated rainfall at their location was around $2 \mathrm{~m}$ reaching an elevation of $16 \mathrm{~m}$ below sea level. A cumulative storage volume curve (see Figure 8) was conducted using the elevation contours at Afouna Village, and it was determined that the elevation of water would reach $-16 \mathrm{~m}$ below sea level at their location if the total runoff volume that would affect Afouna Village was about 13.2 million $\mathrm{m}^{3}$. These results agree with the model results, where the flash flood which occurred in November 2015 corresponded to 13.3 million $\mathrm{m}^{3}$ of total runoff volume for a 100-year return period.

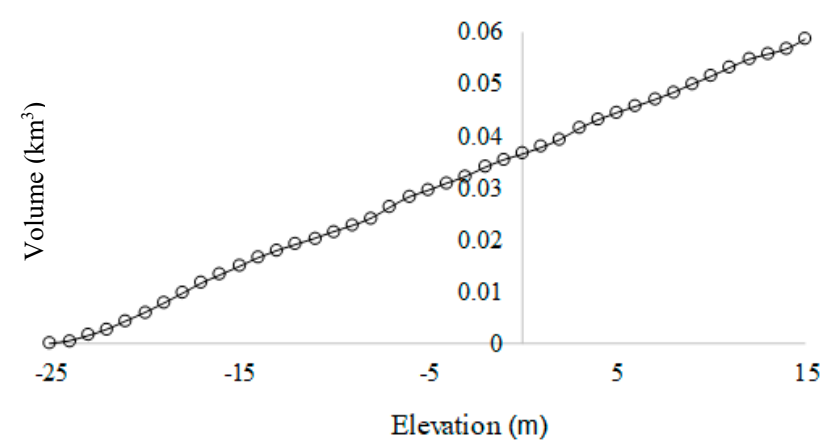

Figure 8. Cumulative storage volume curve for the Afouna Village.

\subsection{Pond Design and Groundwater Recharging}

The total inflow of the pond was retrieved from the HEC-HMS model, which was used as the main design criteria for designing the pond, using the EPA SWMM software. The coefficient of permeability was retrieved from the soil analysis. Then the sizing of the proposed pond was determined for return periods of 50- and 100-years. Analysis of the soil samples collected from the pond area, at depths from 4.0 to $8.0 \mathrm{~m}$, showed that the soil type is silty sand, with a hydraulic conductivity of $2 \times 10^{-4} \mathrm{~m} / \mathrm{s}$. However, the soil type changed to sand, with a hydraulic conductivity of $9.8 \times 10^{-3} \mathrm{~m} / \mathrm{s}$ at depths from 9.0 to $12 \mathrm{~m}$. The hydraulic conductivity of the silty sand until a depth of $8 \mathrm{~m}$ was too low, where the EPA SWMM results showed that the pond depth would exceed $13 \mathrm{~m}$ to avoid flooding. The Hydrus $3 \mathrm{D}$ results also showed that it would take about 430 days to empty the pond through recharging the groundwater. Since it will be challenging to drill a pond with a depth that may exceed $13 \mathrm{~m}$, a novel approach was proposed in this research, which was substituting the silty sand by a highly infiltrated sand with a hydraulic conductivity of $9.6 \times 10^{-3} \mathrm{~m} / \mathrm{s}$, to have a uniform soil profile. Figure 9 shows the soil profile for the current and proposed scenario. By replacement of the soil beneath the pond to a more porous sandy soil, the pond will act as a swale, in which the pond will allow water to infiltrate and/or to provide attenuation storage.

Swales should be shallow, flat bottomed, and vegetated (if possible) to convey and treat surface runoff [80]. Shallow ponds are preferred over deeper ones, as they are more convenient in cleaning the sedimentation and waste. Furthermore, it is better from a public health and safety standpoint. Based on EPA SWMM results, the depth of the pond needed to avoid flooding will reduce from 11 to $4 \mathrm{~m}$ after replacing the silty sand soil with sand, for the layer from depth $4 \mathrm{~m}$ to depth $8 \mathrm{~m}$. Table 4 shows the dimensions of the pond, for 50- and 100-year return periods. 


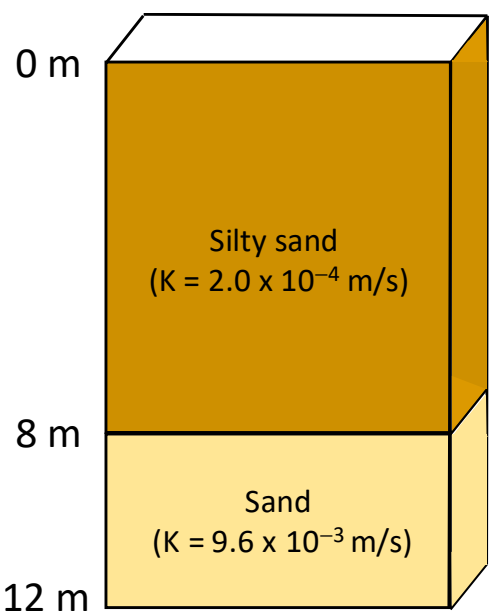

\section{Current situation}

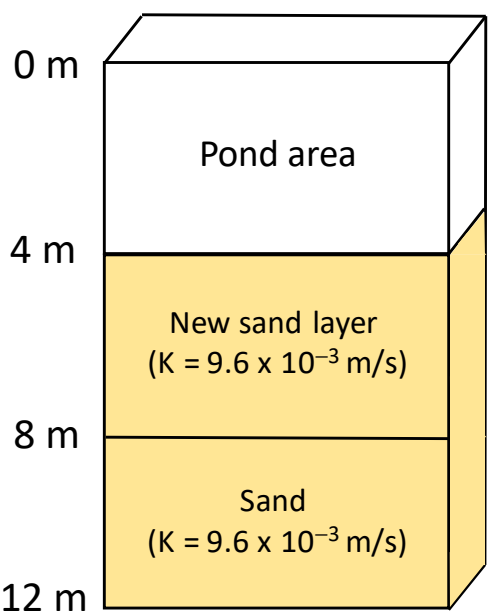

Proposed scenario

Figure 9. Soil profile for the current and proposed scenario.

Table 4. New dimensions of the pond for 50- and 100-year return periods.

\begin{tabular}{ccc}
\hline \multirow{2}{*}{ Depth $(\mathbf{m})$} & \multicolumn{2}{c}{ Area $\left(\mathbf{m}^{\mathbf{2}}\right)$} \\
\cline { 2 - 3 } & $\mathbf{5 0}$ Years & $\mathbf{1 0 0}$ Years \\
\hline 1 & 190,000 & 285,000 \\
2 & 180,000 & 280,000 \\
3 & 170,000 & 275,000 \\
4 & 160,000 & 270,000 \\
\hline
\end{tabular}

The artificial pond captures the runoff and allows the precipitation to be shared between evapotranspiration and groundwater recharge through infiltration. The new soil type that will be imported to the pond area is sandy soil, which is similar to the soil type recorded at depths from 9.0 to $12 \mathrm{~m}$. The hydraulic properties and chemical analysis of this soil were evaluated, and are summarized in Table 5. The average coefficient of permeability $(\mathrm{k})$ for the seven soil samples at depths 4.0, 5.0, 6.0, and $7.0 \mathrm{~m}$ was $9.6 \times 10^{-3} \mathrm{~m} / \mathrm{s}$, which reflects that it is "rapid" infiltration type [81].

Table 5. Average tests result for soil samples collected from the pond area at depths from 9.0 to $12 \mathrm{~m}$.

\begin{tabular}{|c|c|c|c|c|c|c|}
\hline Test & $\mathrm{Cl}^{-}(\%)$ & $\mathrm{SO}_{3}(\%)$ & $\begin{array}{c}\text { Organic } \\
\text { Matter (\%) }\end{array}$ & $\mathrm{pH}$ & \multicolumn{2}{|c|}{$\begin{array}{l}\text { Coefficient of Permeability a } \\
\text { Depths from }(9-12 \mathrm{~m})(\mathrm{m} / \mathrm{s})\end{array}$} \\
\hline Average & 0.028 & 0.018 & 0 & 8.3 & \multirow{2}{*}{\multicolumn{2}{|c|}{$9.8 \times 10^{-3}$}} \\
\hline Egyptian code limits & Less than $0.04 \%$ & Less than $0.04 \%$ & 0 & - & & \\
\hline Soil Type & $\theta_{\mathrm{r}}\left(\mathrm{m}^{-3} \mathrm{~m}^{3}\right)$ & $\theta_{s}\left(m^{-3} m^{3}\right)$ & $\alpha\left(m^{-1}\right)$ & n (-) & $K_{s}(\mathrm{~m} / \mathrm{s})$ & L (-) \\
\hline Sand & 0.045 & 0.43 & 0.145 & 2.68 & $9.6 \times 10^{-3}$ & 0.5 \\
\hline
\end{tabular}

Note: $K_{\mathrm{s}}$ is the saturated hydraulic conductivity; $\theta_{\mathrm{r}}$ is the residual volumetric water content; $\theta_{\mathrm{s}}$ is the saturated water content, which is equal to the soil porosity; $n$ is a pore size distribution index; $l$ is a pore connectivity parameter; $\alpha$ (Alpha) (1/L) and $n(-)$ are empirical coefficients affecting the shape of the hydraulic functions. These values were obtained and utilized based on the saved database stored in Hydrus. Hydrus has a saved database for different soil types.

Owing to the high hydraulic conductivity of the new soil (sandy soil: $K=9.8 \times 10^{-3} \mathrm{~m} / \mathrm{s}$ ), considering the water content and degree of saturation, a more significant amount of water tends to infiltrate into the soil at minimal evapotranspiration rates. Note that the new dimensions were obtained by allowing a new factor in the water budget equation, which is the groundwater recharge through percolation against time. This allows water to infiltrate to the groundwater table during the pond filling. 
After simulation using Hydrus software, the evapotranspiration rate at the study area was estimated to be $5 \mathrm{~mm} /$ day during November 2015. The rate of losses due to evapotranspiration for Scenario 1 at the maximum ponding area of $190 \times 10^{3} \mathrm{~m}^{2}$ and water depth in the pond of $4.0 \mathrm{~m}$, and Scenario 2 at the maximum ponding area of $285 \times 10^{3} \mathrm{~m}^{2}$, and water depth in the pond of $4 \mathrm{~m}$, were determined to be $950 \mathrm{~m}^{3} /$ day and $1425 \mathrm{~m}^{3} /$ day, respectively. The groundwater recharging rates for Scenario 1 and Scenario 2 were determined to be $138 \times 10^{3} \mathrm{~m}^{3} /$ day and $207 \times 10^{3} \mathrm{~m}^{3} /$ day, respectively. Figure 10 shows the relation between the runoff, evapotranspiration, groundwater recharge, and the storage of the pond, concerning time for both scenarios. It can be concluded from the figures that the storm was very intense in its first couple of days and that it lasted four days. The water storage in the pond was estimated to be emptied in nine days, between groundwater recharge and evapotranspiration. Noting that the permeability of the soil is substantially high, the groundwater recharge uses the more substantial portion of water to feed the groundwater aquifer. Stone bunds may also be used at the pond entrance to reduce runoff velocity and bed erosion. Using stone bunds would also increase water infiltration through increasing sediment capture.
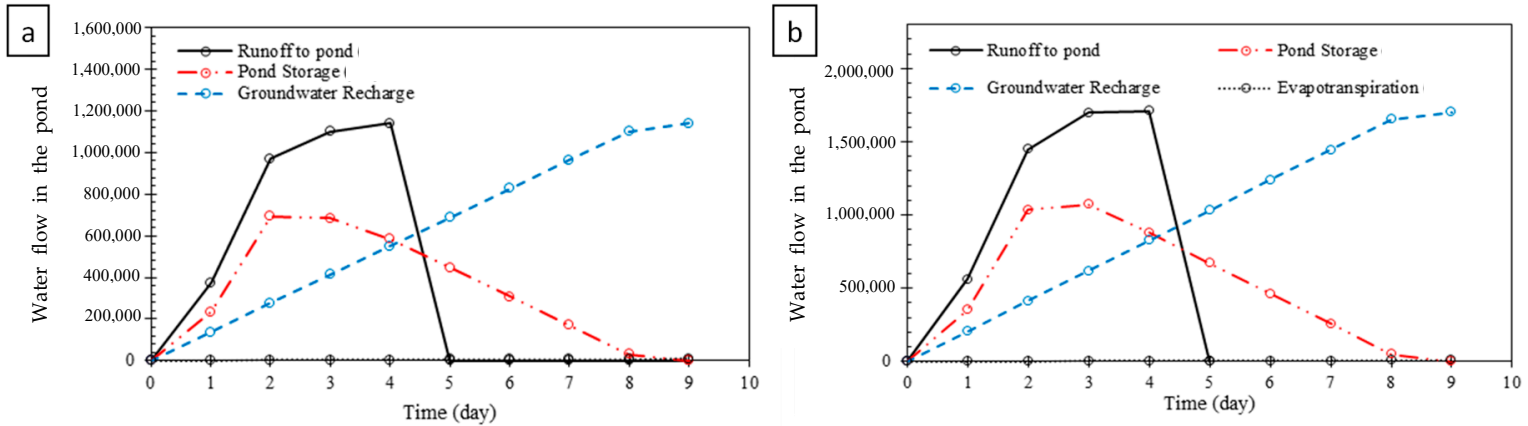

Figure 10. Water flow balance inside the pond: (a) Scenario 1: 50-year return period (b) Scenario 2: 100-year return period.

\subsection{Infiltration Pond Cost Analysis}

A cost analysis study was conducted for the infiltration pond construction. The main costs for the water management construction come from the drilling and lining (pitching). The lining will be applied to the lateral area of the pond, not the base, to allow for groundwater recharge. The cost of drilling and lining was estimated based on quotations received from contractors working in the region of study (Al-Behiera governorate), on 15 of June 2020, for each cubic metre, including labour costs, materials, and transportation (see Table 6). Table 7 shows that the total cost of pond construction (drilling, pitching, and replacing the sand layer) is about $\$ 1,806,250$ and $\$ 2,720,000$ for the 50- and 100-year return periods, respectively.

Table 6. Cost estimation per meter per process.

\begin{tabular}{ccc}
\hline Process & Cost (EGP) & Cost (\$) \\
\hline Drilling & $5\left(\mathrm{EGP} / \mathrm{m}^{3}\right)$ & 0.31 \\
Pitching & $300\left(\mathrm{EGP} / \mathrm{m}^{2}\right)$ & 18.75 \\
$\begin{array}{c}\text { Sand importing to the site } \\
\text { (including cost of the sand) }\end{array}$ & $25\left(\mathrm{EGP} / \mathrm{m}^{3}\right)$ & 1.56 \\
\hline
\end{tabular}

$1 \$=16.0$ EGP (July 2020). 
Table 7. Total cost estimation for each process for the 50- and 100-years return periods.

\begin{tabular}{|c|c|c|c|c|}
\hline Depth & Area, $\left(\mathrm{m}^{2}\right)$ & Radius, (m) & Perimeter, (m) & Lateral Area, $\left(\mathrm{m}^{2}\right)$ \\
\hline \multicolumn{5}{|c|}{50 years Return Period } \\
\hline 1 & 190,000 & 246 & 1545 & 1545 \\
\hline 2 & 180,000 & 239 & 1504 & 1504 \\
\hline 3 & 170,000 & 233 & 1461 & 1461 \\
\hline 4 & 160,000 & 226 & 1418 & 1418 \\
\hline $5-8$ & 160,000 for each $1 \mathrm{~m}$ & 226 for each $1 \mathrm{~m}$ & 1418 for each $1 \mathrm{~m}$ & 1418 for each $1 \mathrm{~m}$ \\
\hline Total & $1,340,000$ & & & 11,600 \\
\hline Drilling cost, EGP & \multicolumn{4}{|c|}{$7,200,000$} \\
\hline Pitching cost, EGP & \multicolumn{4}{|c|}{$3,700,000$} \\
\hline Sand importing cost, EGP & \multicolumn{4}{|c|}{$18,000,000$} \\
\hline Total cost, EGP (\$USD) & \multicolumn{4}{|c|}{$28,900,000(\$ 1,806,250)$} \\
\hline Depth & Area $\left(m^{2}\right)$ & Radius, (m) & Perimeter, $(\mathrm{m})$ & Lateral Area $\left(\mathrm{m}^{2}\right)$ \\
\hline \multicolumn{5}{|c|}{100 years return period } \\
\hline 1 & 285,000 & 301 & 1892 & 1892 \\
\hline 2 & 280,000 & 299 & 1875 & 1875 \\
\hline 3 & 275,000 & 296 & 1858 & 1858 \\
\hline 4 & 270,000 & 293 & 1842 & 1842 \\
\hline $5-8$ & 270,000 for each $1 \mathrm{~m}$ & 293 for each $1 \mathrm{~m}$ & 1842 for each $1 \mathrm{~m}$ & 1842 for each $1 \mathrm{~m}$ \\
\hline Total & $2,190,000$ & & & 14,835 \\
\hline Drilling cost, EGP (\$) & \multicolumn{4}{|c|}{$11,200,000$} \\
\hline Pitching cost, EGP & \multicolumn{4}{|c|}{$4,320,000$} \\
\hline Sand importing cost, EGP & \multicolumn{4}{|c|}{$28,000,000$} \\
\hline Total cost, EGP (\$USD) & \multicolumn{4}{|c|}{$43,520,000(\$ 2,720,000)$} \\
\hline
\end{tabular}




\section{Discussion}

A necessary step in any rainwater harvesting system involves utilizing methods to increase the quantity of water stored in the soil profile, by trapping or holding the rain when it falls [82]. Mbilinyi et al. [83] noted that the identification of potential sites for rainwater harvesting is an essential step towards maximizing the availability of water and land productivity in semi-arid areas. Water harvesting systems provide the benefits of rainwater reuse [84]. The authors pointed out that rainwater harvesting is especially crucial in areas with scarce water resources, such as Egypt [84]. Additional benefits include simplicity of installation, low maintenance, low energy costs, excellent water conservation, it can be adapted in urban and rural regions, and it is an excellent tool for managing water shortage and mitigating drought $[85,86]$. Rainwater harvesting can also provide additional water for agriculture, industrial, commercial, and private use, along with reduced flood risk [87].

Chivenge et al. [88] recognized the importance of traditional, small-scale rainwater harvesting systems in sub-Saharan Africa. In situ water harvesting can be used to provide water for agricultural use in arid regions, where there is no surface water available for human activities [82]. They concluded that in situ water harvesting can be used to provide water for agriculture in arid regions. Additionally, in rural locations, rainwater can also be collected from roof surfaces for consumption. Collection of surface water runoff can reduce flood damage [89]. They further note that rainwater harvesting could reduce flood frequency and surface runoff during storms. Factors causing minor flooding are numerous, and widely varied in nature; those factors vary widely from one case to another [90]. Therefore, it is vital to analyze each local context to define a strategy for reducing blockages [90]. Ramakrishnan et al. [71] used slope, permeability, porosity, runoff potential, stream order, and catchment area as primary criteria for selection of suitable sites for various rainwater harvesting systems in the KALI Watershed, Dahod district of Gujarat, India. Similarly, Durga Rao et al. [72] utilized land use, soil texture, slope, runoff potential, geology, proximity, and drainage as primary factors to identify suitable rainwater harvesting sites. Rainwater utilization provides a low-cost solution that provides fresh water for various sources [87]. As water availability becomes more and more constrained, rainwater harvesting offers a viable solution for improved stormwater management [91]. In this study, a novel approach was proposed by substituting the low permeability sand with a high permeability, which will enhance water harvesting, reduce direct evaporation, and conserve water for future use, since people in this area depend mainly on groundwater for drinking and irrigation.

\section{Conclusions}

This study provides a sustainable solution for rural communities in arid and semi-arid regions that suffer from the havoc of extensive flash floods. The rainfall data were retrieved from TRMM satellite data since the study area is ungauged. However, it is recommended to install a rainfall monitoring system in the study area to monitor rainfall with high accuracy, and to be able to track historical records. Integrated hydrological modelling techniques were used for flood hydrological simulation, groundwater recharging, and designing of the infiltration pond. In this study, the infiltration pond was found to be a good solution for rural communities that rely mainly on groundwater. A novel approach was proposed, which is substituting the low permeability silty sand $\left(2.0 \times 10^{-4} \mathrm{~m} / \mathrm{s}\right)$ in the bottom of the pond with a high permeability one $\left(9.6 \times 10^{-3} \mathrm{~m} / \mathrm{s}\right)$, which will enhance water harvesting and reduce direct evaporation. The Hydrus $3 \mathrm{D}$ results showed that by replacing the soil type, the time needed to empty the pond through recharging the groundwater would drop from 430 days to 9 days, which will also reduce water loss through evaporation. The maximum groundwater recharging rates for the proposed infiltration ponds were estimated at $138 \times 10^{3} \mathrm{~m}^{3} /$ day and $207 \times 10^{3} \mathrm{~m}^{3} /$ day for 50 and 100-year rainfall return periods, respectively. The cost analysis of the two ponds were $\$ 1,806,250$ and $\$ 2,720,000$ for return periods of 50 and 100 years, respectively. 
Supplementary Materials: The following are available online at http://www.mdpi.com/2073-4441/12/9/2565/s1, Figure S1: Soil texture in the study region, Table S1. Akaike information criterion for different fitting distributions.

Author Contributions: Conceptualization, M.K.M. and R.W.P.; Data curation, O.M.A., O.E., M.M.H., A.A., H.H.M. and K.M.M.; Formal analysis, O.M.A. and M.K.M.; Funding acquisition, M.K.M.; Investigation, O.M.A., O.E., M.K.M. and K.M.M.; Methodology, O.E. and M.K.M.; Project administration, M.K.M.; Software, O.M.A. and M.K.M.; Supervision, M.K.M.; Validation, O.M.A., M.K.M. and A.A.; Visualization, O.M.A., O.E., M.K.M. and A.A.; Writing - original draft, O.M.A., O.E. and M.K.M.; Writing - review \& editing, O.E., M.K.M., M.M.H., A.A. and R.W.P. All authors have read and agree to the published version of the manuscript.

Funding: The APC was funded by TU Delft Open Access Program.

Acknowledgments: This work was supported by Zewail City of Science and Technology and Badr University in Cairo. This research publication was funded by TU Delft Open Access Program. Special thanks to Mohamed Amer and the Housing and Building National Research Center (HBRC) staff for helping in collecting soil samples and performing the analyses.

Conflicts of Interest: The authors declare no conflict of interest.

\section{References}

1. El-Afandi, G.; Morsy, M. Developing an early warning system for flash flood in Egypt: Case study Sinai Peninsula. In Flash Floods in Egypt; Negm, A.M., Ed.; Springer: Berlin, Germany, 2019.

2. Fathy, I.; Abd-Elhamid, H.F.; Negm, A.M. Prediction and mitigation of flash floods in egypt. In Flash Floods in Egypt; Negm, A.M., Ed.; Springer: Berlin, Germany, 2019.

3. Kumar, A.; Gupta, A.K.; Bhambri, R.; Verma, A.; Tiwari, S.K.; Asthana, A.K.L. Assessment and review of hydrometeorological aspects for cloudburst and flash flood events in the third pole region (Indian Himalaya). Polar Sci. 2018, 18, 5-20. [CrossRef]

4. Lin, X. Flash floods in arid and semi-arid zones. In Proceedings of the Technical Documents in Hydrology, Paris, France, 1999. Available online: https:/pdfs.semanticscholar.org/49b8/ 4acb36dba77bf01dcbf453974e3a160a018e.pdf?_ga=2.37376672.1055313888.1599730210-2051002838. 1589894070 (accessed on 9 September 2020).

5. Archer, D.R.; Fowler, H.J. Characterising flash flood response to intense rainfall and impacts using historical information and gauged data in Britain. J. Flood Risk Manag. 2018, 11, S121-S133. [CrossRef]

6. Faccini, F.; Luino, F.; Paliaga, G.; Sacchini, A.; Turconi, L.; de Jong, C. Role of rainfall intensity and urban sprawl in the 2014 flash flood in Genoa City, Bisagno catchment (Liguria, Italy). Appl. Geogr. 2018, 98, 224-241. [CrossRef]

7. U.S. Department of Commerce. Flood and Flash Flood Definitions; NOAA, National Weather Service, Ed.; NOAA: Miami, FL, USA, 2015.

8. Mashaly, J.; Ghoneim, E. Flash flood hazard using optical, radar, and stereo-pair derived dem: Eastern desert, egypt. Remote Sens. 2018, 10, 1204. [CrossRef]

9. Youssef, A.M.; Hegab, M.A. Flood-hazard assessment modeling using multicriteria analysis and gis. In Spatial Modeling in GIS and R for Earth and Environmental Sciences; Elsevier: Amsterdam, The Netherlands, 2019; pp. 229-257. [CrossRef]

10. Cools, J.; Vanderkimpen, P.; El Afandi, G.; Abdelkhalek, A.; Fockedey, S.; El Sammany, M.; Abdallah, G.; El Bihery, M.; Bauwens, W.; Huygens, M. An early warning system for flash floods in hyper-arid Egypt. Nat. Hazards Earth Syst. Sci. 2012, 12, 443-457. [CrossRef]

11. National Aeronautics and Space Administration (NASA). Rare Storm over Mediterranean Sea. Available online: https://modis.gsfc.nasa.gov/gallery/individual.php?db_date=2019-10-26 (accessed on 30 October 2019).

12. Negm, A.M.; Omran, E.-S.E. Introduction to "flash floods in Egypt". In Flash Floods in Egypt; Negm, A.M., Ed.; Springer: Berlin, Germany, 2019.

13. Romero, R.; Emanuel, K. Climate change and hurricane-like extratropical cyclones: Projections for north atlantic polar lows and medicanes based on CMIP5 models. J. Clim. 2017, 30, 279-299. [CrossRef]

14. Cooke, R.U.; Brunsden, D.; Doornkamp, J.C. Urban Geomorphology in Drylands; Oxford University Press: Oxford, UK, 1982; p. 324.

15. Abuzied, S.; Yuan, M.; Ibrahim, S.; Kaiser, M.; Saleem, T. Geospatial risk assessment of flash floods in Nuweiba area, Egypt. J. Arid Environ. 2016, 133, 54-72. [CrossRef] 
16. Gabr, S.; El Bastawesy, M. Estimating the flash flood quantitative parameters affecting the oil-fields infrastructures in Ras Sudr, Sinai, Egypt, during the January 2010 event. Egypt. J. Remote Sens. Space Sci. 2015, 18, 137-149. [CrossRef]

17. Monsef, H.A.-E. A mitigation strategy for reducing flood risk to highways in arid regions: A case study of the El-Quseir-Qena highway in Egypt. J. Flood Risk Manag. 2018, 11, S158-S172. [CrossRef]

18. Omran, E.-S.E. Egypt's Sinai desert cries: Flash flood hazard, vulnerability, and mitigation. In Flash Floods in Egypt; Negm, A.M., Ed.; Springer: Berlin, Germany, 2019.

19. Ebaid, H.M.; Farag, H.A.; Falaky, A.A.E. Using gis and remote sensing approaches to delineate potential areas for runoff management applications in Egypt. Int. J. Environ. Sci. Eng. (IJESE) 2016, 7, 85-93.

20. Abu Elfadl, J.; Gouda, N. Flood Losses Report, Youm7. 2015. Available online: https://bit.ly/3idaBVn (accessed on 9 September 2020).

21. Chan, N.W.; Ghani, A.A.; Samat, N.; Hasan, N.N.N.; Tan, M.L. Integrating structural and non-structural flood management measures for greater effectiveness in flood loss reduction in the kelantan river basin, malaysia. In Proceedings of the AICCE'19: Transforming the Nation for a Sustainable Tomorrow, Penang, Malaysia, 21-22 August 2019; pp. 1151-1162.

22. Kumar, M.; Sharif, M.; Ahmed, S. Flood risk management strategies for national capital territory of Delhi, India. ISH J. Hydraul. Eng. 2017, 25, 248-259. [CrossRef]

23. Plate, E.J. Flood risk and flood management. J. Hydrol. 2002, 267, 2-11. [CrossRef]

24. Zhu, Z.; Chen, X. Evaluating the effects of low impact development practices on urban flooding under different rainfall intensities. Water 2017, 9, 548. [CrossRef]

25. Peter, A.; Mathew, A. Structural flood defence measures and effects on the surroundings. EPH Int. J. Appl. Sci. 2018, 4, 1-14.

26. Destro, E.; Amponsah, W.; Nikolopoulos, E.I.; Marchi, L.; Marra, F.; Zoccatelli, D.; Borga, M. Coupled prediction of flash flood response and debris flow occurrence: Application on an alpine extreme flood event. J. Hydrol. 2018, 558, 225-237. [CrossRef]

27. Hasan, A.S.; Saha, R.R. A Study on the flood damage and mitigation measures of floods occurring in Bangladesh at the last decade. In Proceedings of the 1st National Conference on Water Resources Engineering (NCWRE), Chittagong University of Engineering and Technology, Chittagong, Bangladesh, 21-22 March 2018.

28. Sikorska, A.E.; Viviroli, D.; Seibert, J. Effective precipitation duration for runoff peaks based on catchment modelling. J. Hydrol. 2018, 556, 510-522. [CrossRef]

29. Kim, R.H.; Lee, S.; Kim, Y.M.; Lee, J.H.; Kim, S.K.; Kim, S.G. Pollutants in rainwater runoff in Korea: Their impacts on rainwater utilization. Environ. Technol. 2005, 26, 411-420. [CrossRef]

30. Kundzewicz, Z.W.; Su, B.; Wang, Y.; Xia, J.; Huang, J.; Jiang, T. Flood risk and its reduction in China. Adv. Water Resour. 2019, 130, 37-45. [CrossRef]

31. de Ruig, L.T.; Haer, T.; de Moel, H.; Botzen, W.J.W.; Aerts, J.C.J.H. A micro-scale cost-benefit analysis of building-level flood risk adaptation measures in Los Angeles. Water Resour. Econ. 2019, 100147. [CrossRef]

32. Di Baldassarre, G.; Kreibich, H.; Vorogushyn, S.; Aerts, J.; Arnbjerg-Nielsen, K.; Barendrecht, M.; Bates, P.; Borga, M.; Botzen, W.; Bubeck, P.; et al. Hess opinions: An interdisciplinary research agenda to explore the unintended consequences of structural flood protection. Hydrol. Earth Syst. Sci. 2018, 22, 5629-5637. [CrossRef]

33. Shah, M.A.R.; Rahman, A.; Chowdhury, S.H. Challenges for achieving sustainable flood risk management. J. Flood Risk Manag. 2018, 11, S352-S358. [CrossRef]

34. Giri, B.S.; Gun, S.; Pandey, S.; Trivedi, A.; Kapoor, R.T.; Singh, R.P.; Abdeldayem, O.M.; Rene, E.R.; Yadav, S.; Chaturvedi, P.; et al. Reusability of brilliant green dye contaminated wastewater using corncob biochar and Brevibacillus parabrevis: Hybrid treatment and kinetic studies. Bioengineered 2020, 11, 743-758. [CrossRef] [PubMed]

35. Ramírez Calderón, O.A.; Abdeldayem, O.M.; Pugazhendhi, A.; Rene, E.R. Current updates and perspectives of biosorption technology: An alternative for the removal of heavy metals from wastewater. Curr. Pollut. Rep. 2020, 6, 8-27. [CrossRef]

36. Al-Sakkari, E.G.; Abdeldayem, O.M.; Genina, E.E.; Amin, L.; Bahgat, N.T.; Rene, E.R.; El-Sherbiny, I.M. New alginate-based interpenetrating polymer networks for water treatment: A response surface methodology based optimization study. Int. J. Biol. Macromol. 2020, 155, 772-785. [CrossRef] 
37. United Nations. About the Sustainable Development Goals. Available online: https://www.un.org/ sustainabledevelopment/sustainable-development-goals/ (accessed on 20 June 2020).

38. Abdelhafez, A.A.; Metwalley, S.M.; Abbas, H.H. Irrigation: Water resources, types and common problems in Egypt. In Technological and Modern Irrigation Environment in Egypt; Negm, A., Ed.; Springer Water: Cham, Switzerland, 2020; pp. 15-34. [CrossRef]

39. Yassen, A.N.; Nam, W.-H.; Hong, E.-M. Impact of climate change on reference evapotranspiration in Egypt. Catena 2020, 194. [CrossRef]

40. Abdelrady, A.; Sharma, S.; Sefelnasr, A.; El-Rawy, M.; Kennedy, M. Analysis of the Performance of Bank Filtration for Water Supply in Arid Climates: Case Study in Egypt. Water 2020, 12, 1816. [CrossRef]

41. Rajasekhar, M.; Gadhiraju, S.R.; Kadam, A.; Bhagat, V. Identification of groundwater recharge-based potential rainwater harvesting sites for sustainable development of a semiarid region of southern India using geospatial, AHP, and SCS-CN approach. Arab. J. Geosci. 2020, 13. [CrossRef]

42. Wakode, H.B.; Baier, K.; Jha, R.; Azzam, R. Impact of urbanization on groundwater recharge and urban water balance for the city of Hyderabad, India. Int. Soil Water Conserv. Res. 2018, 6, 51-62. [CrossRef]

43. Allen, V. Rainwater harvesting and recharge techniques for flood control and improved stormwater quality. In Proceedings of the 55th Annual NM Water Conference, How Will Institutions Evolve to Meet Our Water Needs in the Next Decade? Corbett Center, New Mexico State University, Las Cruces, NM, USA, 1-3 December 2010.

44. Khan, D.; Rahman, S.; Haque, A.; Chen, A.; Hammond, M.; Djordjevi, S.; Butler, D. Flood damage assessment for Dhaka City, Bangladesh. In Comprehensive Flood Risk Management; CRC Press: Boca Raton, FL, USA, 2012. [CrossRef]

45. Hu, M.; Zhang, X.; Li, Y.; Yang, H.; Tanaka, K. Flood mitigation performance of low impact development technologies under different storms for retrofitting an urbanized area. J. Clean. Prod. 2019, 222, 373-380. [CrossRef]

46. Freni, G.; Liuzzo, L. Effectiveness of rainwater harvesting systems for flood reduction in residential urban areas. Water 2019, 11, 1389. [CrossRef]

47. Oirere, S. Rainwater Harvesting Seen as Solution for Drought and Flood Control. Available online: https://www.alternet.org/2009/04/rainwater_harvesting_seen_as_solution_for_drought_and_flood_ control/ (accessed on 14 July 2020).

48. Prinz, D.; Singh, A. Technological Potential for Improvements of Water Harvesting. Available online: http://web.stanford.edu/ \{\}cbauburn/basecamp/dschool/homeproject/water_harvesting_improvements_ technology.pdf (accessed on 9 September 2020).

49. Borodinecs, A.; Davydov, R.; Antonov, V.; Molodtsov, D.; Cheremisin, A.; Korablev, V.; Sergeev, V.; Vatin, N. The simulation model for a flood management by flood control facilities. MATEC Web Conf. 2018, 245. [CrossRef]

50. Komolafe, A.A.; Herath, S.; Avtar, R. Development of generalized loss functions for rapid estimation of flood damages: A case study in Kelani River basin, Sri Lanka. Appl. Geomat. 2017, 10, 13-30. [CrossRef]

51. Ahiabor, G. Rainwater Harvesting: An Answer to Urban Flood Control. Available online: https://www. graphic.com.gh/features/features/rainwater-harvesting-an-answer-to-urban-flood-control.html (accessed on 14 July 2020).

52. Duc Tran, D.; van Halsema, G.; Hellegers, P.J.G.J.; Phi Hoang, L.; Quang Tran, T.; Kummu, M.; Ludwig, F. Assessing impacts of dike construction on the flood dynamics of the Mekong Delta. Hydrol. Earth Syst. Sci. 2018, 22, 1875-1896. [CrossRef]

53. Karamouz, M.; Heydari, Z. Conceptual design framework for coastal flood best management practices. J. Water Resour. Plan. Manag. 2020, 146. [CrossRef]

54. Omran, E.-S.E. Egypt's Sinai desert cries: Utilization of flash flood for a sustainable water management. In Flash Floods in Egypt; Negm, A.M., Ed.; Springer: Berlin, Germany, 2019.

55. Morsy, K.M.; Morsy, A.M.; Hassan, A.E. Groundwater sustainability: Opportunity out of threat. Groundw. Sustain. Dev. 2018, 7, 277-285. [CrossRef]

56. Smith, K.; Ward, R. Floods: Physical Processes and Human Impacts; Wiley: Hoboken, NJ, USA, 1998.

57. Zhao, W.; Ma, J. Landscape applications of rainwater resources in urban green space: A case study of green space reconstruction along Riverside Street in Suzhou. In Proceedings of the IOP Conference Series: Earth and Environmental Science, Hangzhou, China, 17-19 July 2019. 
58. Laity, J.J. Deserts and Desert Environments; John Wiley \& Sons: New York, NY, USA, 2008; Volume 3, p. 360.

59. Wheater, H.; Al-Weshah, R.A. Hydrology of wadi systems. In Proceedings of the Technical documents in hydrology, Paris, France, 2002. Available online: https://hydrologie.org/BIB/Publ_UNESCO/TD_055_2002.pdf (accessed on 9 September 2020).

60. U.S. Geological Survey (USGS). Shuttle Radar Topography Mission (SRTM) 1 Arc-Second Global. Available online: https://www.usgs.gov/centers/eros/science/usgs-eros-archive-digital-elevation-shuttleradar-topography-mission-srtm-non?qt-science_center_objects=0\#qt-science_center_objects (accessed on 14 July 2020).

61. U.S. Department of Agriculture (USDA). Urban Hydrology for Small Watersheds; Soil Conservation Service: Washington, DC, USA, 1986.

62. U.S. Department of Agriculture (USDA). Design Hydrographs. In National Engineering Handbook, Part 630; Soil Conservation Service: Washington, DC, USA, 1972.

63. Mishra, S.K.; Singh, V.P. Soil Conservation Service Curve Number (Scs-Cn) Methodology; Springer Science and Business Media Dordrecht: Berlin, Germany, 2003; Volume 42.

64. Jenner, L. NASA-NASA's Goddard Space Flight Center. Available online: https://www.nasa.gov/goddard (accessed on 14 July 2020).

65. National Aeronautics and Space Administration (NASA). Total Rainfall. Available online: https: //earthobservatory.nasa.gov/global-maps/TRMM_3B43M (accessed on 30 October 2019).

66. McBain, W. Twenty-first century flood risk management. In Flood Risk; ICE: London, UK, 2012; pp. 7-22. [CrossRef]

67. Padiyedath Gopalan, S.; Kawamura, A.; Takasaki, T.; Amaguchi, H.; Azhikodan, G. An effective storage function model for an urban watershed in terms of hydrograph reproducibility and Akaike information criterion. J. Hydrol. 2018, 563, 657-668. [CrossRef]

68. Egyptian Code for Soil Mechanics and Foundation Design and Execution; Code No. 202/7; Seventh Part; Retaining Structure: Cairo, Egypt, 2007.

69. Bube, K.P.; Trimble, S.W. Revision of the churchill reservoir trap efficiency curves using smoothing splines. Water Resour. Bull. 1986, 22, 1-5. [CrossRef]

70. United States Environmental Protection Agency (U.S. EPA). Storm Water Management Model (SWMM). Available online: https://www.epa.gov/water-research/storm-water-management-model-swmm (accessed on 14 July 2020).

71. Ramakrishnan, D.; Bandyopadhyay, A.; Kusuma, K.N. SCS-CN and GIS-based approach for identifying potential water harvesting sites in the Kali Watershed, Mahi River Basin, India. J. Earth Syst. Sci. 2009, 118, 355-368. [CrossRef]

72. Durga Rao, K.H.V.; Bhaumik, M.K. Spatial expert support system in selecting suitable sites for water harvesting structures-A case study of song watershed, Uttaranchal, India. Geocarto Int. 2003, 18, 43-50. [CrossRef]

73. Šimůnek, J.; van Genuchten, M.T.; Šejna, M. Development and applications of the HYDRUS and STANMOD software packages and related codes. Vadose Zone J. 2008, 7, 587-600. [CrossRef]

74. National Aeronautics and Space Administration (NASA). Rainfall Estimate Per Month. Available online: https://giovanni.gsfc.nasa.gov/giovanni (accessed on 14 July 2020).

75. Abdulrazzak, M.; Elfeki, A.; Kamis, A.S.; Kassab, M.; Alamri, N.; Noor, K.; Chaabani, A. The impact of rainfall distribution patterns on hydrological and hydraulic response in arid regions: Case study Medina, Saudi Arabia. Arab. J. Geosci. 2018, 11. [CrossRef]

76. Patle, G. Probability analysis of consecutive days annual maximum rainfall for the design of surface drains in semi-arid Maharastra. Indian J. Soil Conserv. 2008, 36, 144-147.

77. Barkotulla, M.; Rahman, M.; Rahman, M. Characterization and frequency analysis of consecutive days maximum rainfall at Boalia, Rajshahi and Bangladesh. J. Dev. Agric. Econ. 2009, 1, 121-126.

78. Tilahun, K. The characterisation of rainfall in the arid and semi-arid regions of Ethiopia. Water SA $2007,32$. [CrossRef]

79. Kwaku, X.S.; Duke, O. Characterization and frequency analysis of one day annual maximum and two to five consecutive days maximum rainfall of Accra, Ghana. ARPN J. Eng. Appl. Sci. 2007, 2, 27-31.

80. Ballard, B.W.; Wilson, S.; Udale-Clarke, H.; Illman, S.; Scott, T.; Ashley, R.; Kellagher, R. The SuDS Manual; CIRIA Publication: London, UK, 2015. 
81. Faures, J.M.; Eliasson, A.; Hoogeveen, J.; Vallee, D. AQUASTAT-FAO's information system on water and agriculture. In GRID-Magazine of the IPTRID Network (FAO/United Kingdom); FAO: Rome, Italy, 2001.

82. Mahmoud, S.H.; Alazba, A.A. The potential of in situ rainwater harvesting in arid regions: Developing a methodology to identify suitable areas using GIS-based decision support system. Arab. J. Geosci. 2014, 8, 5167-5179. [CrossRef]

83. Mbilinyi, B.P.; Tumbo, S.D.; Mahoo, H.F.; Mkiramwinyi, F.O. GIS-based decision support system for identifying potential sites for rainwater harvesting. Phys. Chem. Earth Parts A/B/C 2007, 32, 1074-1081. [CrossRef]

84. Zhang, D.; Gersberg, R.M.; Wilhelm, C.; Voigt, M. Decentralized water management: Rainwater harvesting and greywater reuse in an urban area of Beijing, China. Urban Water J. 2009, 6, 375-385. [CrossRef]

85. Mahmoud, W.H.; Elagib, N.A.; Gaese, H.; Heinrich, J. Rainfall conditions and rainwater harvesting potential in the urban area of Khartoum. Resour. Conserv. Recycl. 2014, 91, 89-99. [CrossRef]

86. Thomas, D.B. Soil and Water Conservation Manual for Kenya; SWCB, Ministry of Agriculture and Livestock Development and Marketing: Nairobi, Kenya, 1997.

87. Paul, J.G. Rainwater management to prevent flooding and to enhance urban ecosystem services. In Proceedings of the 3rd International Rainwater Management Conference, Iloilo City, Panay, Philippines, 24-26 November 2010.

88. Chivenge, P.; Mabhaudhi, T.; Modi, A.T.; Mafongoya, P. The potential role of neglected and underutilised crop species as future crops under water scarce conditions in Sub-Saharan Africa. Int. J. Environ. Res. Public Health 2015, 12, 5685-5711. [CrossRef]

89. Mehrabadi, M.H.R.; Motevalli, M. Operation of rainwater harvesting on the roofs of residential buildings to reduce of urban flood: A case study in Tehran, Iran. World Appl. Sci. J. 2012, 17, 264-270.

90. Cherqui, F.; Belmeziti, A.; Granger, D.; Sourdril, A.; Le Gauffre, P. Assessing urban potential flooding risk and identifying effective risk-reduction measures. Sci. Total Environ. 2015, 514, 418-425. [CrossRef] [PubMed]

91. Pavelic, P.; Srisuk, K.; Saraphirom, P.; Nadee, S.; Pholkern, K.; Chusanathas, S.; Munyou, S.; Tangsutthinon, T.; Intarasut, T.; Smakhtin, V. Balancing-out floods and droughts: Opportunities to utilize floodwater harvesting and groundwater storage for agricultural development in Thailand. J. Hydrol. 2012, 470-471, 55-64. [CrossRef] 